УДК 619: 614. 31: 637

(C) 2015

Щербакова Н. С., кандидат ветеринарних наук,

Передера Ж. О., кандидат ветеринарних наук,

Передера С. Б., кандидат ветеринарних наук,

Лубенська А. Ю., студентка

Полтавська державна аграрна академія

\title{
ЗНЕЗАРАЖЕННЯ КОВБАСНИХ ВИРОБІВ ЗА ДОПОМОГОЮ МІКРОХВИЛЬ
}

\section{Рецензент - доктор ветеринарних наук А. А. Замазій}

Наведено дані про знезараження ковбасних виробів НВЧ-хвилями. Встановлено, ше на зменшення кількості мікроорганізмів у ковбасних виробах впливають режим потужності мікрохвильової печі та час обробки зразків. Визначено, шзо час обробки проби має більш значний вплив на зменшення кількості мікроорганізмів у ній, аніж вибраний режим потужності мікрохвильової печі. Тривале опромінення виробів НВЧ-хвилями (протягом трьох хвилин) сприяє знищенню більшої кількості мікроорганізмів, але мінімальний час (1 хвилина) достатній для зменшення кількості мікрофлори ковбасного виробу сумнівної свіжості для того, щьоб вважати його не шкідливим для організму людини після знезараження.

Ключові слова: НВЧ-випромінювання, мікроорганізми, знезараження, харчові токсикозінфекиії.

Постановка проблеми. На даний час, не дивлячись на профілактичні заходи, харчові токсикоінфекції становлять небезпеку для людей майже в усьому світі.

Харчові токсикоінфекції у людей, викликані вживанням м'ясних продуктів, найчастіше, $є$ результатом їх недостатньої теплової обробки або наслідком вторинного інфікування під час порушення технології переробки та зберігання м'яса й м'ясопродуктів [1].

У зв'язку з цим, неабиякого значення набувають питання щодо знешкодження м'яса та м'ясопродуктів з метою повної безпеки готової продукції для споживачів [2].

Аналіз основних досліджень і публікацій, у яких започатковано розв'язання проблеми. В останні роки для вирішення означених вище питань окрім існуючих способів знезараження (проварювання, заморозка, соління) запропоновано використання ультрафіолетових променів, іонізуючого та електромагнітного випромінювання та інше. Поряд із ними, безумовно, стоїть i надвисока частота електромагнітного випромінювання, або НВЧ-обробка харчових продуктів $[1,3,4]$.

Вплив НВЧ-випромінювання на клітини та ор- ганізм у цілому є предметом ретельного вивчення. Використання НВЧ-енергії в медичній, харчовій та мікробіологічній промисловості обумовлено специфікою НВЧ-нагрівання предметів, які піддаються опроміненню, а саме: можливість одночасно нагрівати весь об'єм, регулювати швидкість поглинання енергії й температуру зразка. Теплова обробка необхідна для стерилізації харчових продуктів та різних біологічних об'єктів за максимально можливого збереження їх поживних властивостей $[1,3]$.

Один з основних напрямів використання НВЧенергіï - це застосування іiї у якості фактору активного впливу на клітини мікроорганізмів та їх токсини 3 метою знищення. 3'ясування механізму дії НВЧ-енергіï на мікробну клітину залишається найважливішим теоретичним завданням у процесі вивчення перспектив іiі використання у ветеринарній медицині $[3,4]$.

Таким чином, сукупність усього матеріалу, накопиченого до цього часу 3 даної проблеми, вказує, що НВЧ-енергія виявляє різноманітний вплив на організми різної будови. У ході поглибленого вивчення цих питань відкривається перспектива розробки енергозберігаючих технологій знешкодження, стерилізації або пастеризації за допомогою НВЧ-енергії м'яса, м'ясопродуктів (зокрема ковбасних виробів), м'ясних боєнських відходів, рибопродуктів [3].

Ковбасні вироби - це продукти з м'ясного фаршу із сіллю та спеціями, в оболонці чи без неї, піддані термічній обробці або ферментації до готовності для споживання. У країнах СНД випускають понад 200 найменувань ковбасних виробів. Залежно від технологічного процесу їх поділяють на копчені, напівкопчені, варені, ліверні, м'ясо-рослинні, дієтичні, кров'яні ковбаси та холодці, м'ясні хліби, сальтисони і паштети.

Для приготування ковбасних виробів використовують різноманітну сировину і допоміжні матеріали: м'ясо, субпродукти, жир, кров, молочні, яєчні та борошняні продукти, білкові стабіліза- 


\section{ВЕТЕРИНАРНА МЕДИЦИНА}

тори, посолочні суміші (сіль, цукор, нітрати), спеції, цибуля, часник та інші компоненти. Саме вони $є$ джерелом бактеріального обсіменіння готової продукції. Мікрофлора ковбасних виробів представлена молочнокислими бактеріями, дріжджами, бактеріями групи кишкової палички, сальмонелами, протеєм, золотистим стафілококом, клостридіями [2].

Мета досліджень - вивчення впливу НВЧвипромінювання на ковбасні вироби та визначення його ефективності.

Завдання - встановити оптимальні режими впливу НВЧ-випромінювання на ковбасні вироби з метою їх знезараження.

Матеріали та методи досліджень. Матеріалом нашого дослідження були ковбасні вироби різного ступеня свіжості.

Органолептична оцінка ковбасного виробу проводилася згідно з ГОСТ 9959-91. Мікроскопічний аналіз мазків-відбитків 3 ковбасного виробу проводили згідно з ГОСТ 23392-78.

Результати досліджень. Для контролю впливу НВЧ-хвиль різної потужності та різної експозиції на кількість мікроорганізмів у ковбасних виробах різного ступеня свіжості було використано метод мікроскопії мазків-відбитків із ковбасних виробів до та після обробки їх мікрохвилями. Результати мікроскопічних досліджень наведені у таблиці.

Як можемо бачити 3 даних таблиці, НВЧ-хвилі дійсно впливають на кількість мікроорганізмів, що знаходяться у ковбасних виробах. Однак ступінь впливу залежить від режиму потужності мікрохвильової печі та часу обробки проб, які неоднаково впливають на результат опромінення продукціі. Під час проведення досліджень було виявлено, що в разі використання режиму потужності у 950 Вт було досягнуто кращих результатів із знезараження ковбасного виробу, ніж за використання 450 Вт.

Однак, як показано у таблиці, вирішальним показником є час обробки проб, оскільки за однакового режиму потужності в 450 Вт було знищено більшу кількість мікроорганізмів у разі обробки ковбасного виробу протягом трьох хвилин - у полі зору мазка-відбитка було знайдено в середньому три мікроорганізми, тоді як за обробки протягом однієї хвилини - 11 мікроорганізмів у полі зору мазка-відбитка.

Те саме стосується й інших режимів потужності: під час використання режиму потужності 600 Вт результатом обробки проби протягом трьох хвилин стало 2 мікроорганізми в полі зору мікропрепарату, а протягом однієї хвилини - 9; під час використання режиму потужності 950 Вт протягом трьох хвилин кількість мікроорганізмів у полі зору мазка-відбитка зменшилась із 29 до одного мікроорганізму, а протягом однієї хвилини - із 28 до трьох мікроорганізмів.

Також можливим є визначення ефективності знезараження ковбасного виробу за допомогою НВЧ-опромінення у відсотках. Так, у пробі № 1 до опромінення було виявлено в середньому 26 мікроорганізмів у полі зору мазка-відбитка. Після обробки іiі НВЧ-хвилями потужністю 450 Вт протягом однієї хвилини кількість мікроорганізмів зменшилася до одинадцяти. Шляхом підрахунків знаходимо відсоток ефективності обробки, який становить 57,7. У такий же спосіб можна визначити відсоток ефективності обробки інших проб, який представлений на гістограмі.

\section{Результати мікроскопічних досліджень}

\begin{tabular}{|c|c|c|c|c|c|}
\hline 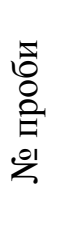 & $\begin{array}{c}\text { Кількість мікро- } \\
\text { організмів у конт- } \\
\text { рольній пробі } \\
\text { (свіжий ковбас- } \\
\text { ний виріб)* }\end{array}$ & $\begin{array}{c}\text { Кількість мікро- } \\
\text { організмів у про- } \\
\text { бі з сумнівного за } \\
\text { свіжістю ковбас- } \\
\text { ного виробу* }\end{array}$ & $\begin{array}{c}\text { Час } \\
\text { обробки } \\
\text { проб, хв. }\end{array}$ & $\begin{array}{c}\text { Потужність } \\
\text { мікрохвильової } \\
\text { печі, Вт }\end{array}$ & $\begin{array}{c}\text { Кількість } \\
\text { мікроорганізмів } \\
\text { після обробки } \\
\text { проб* }\end{array}$ \\
\hline 1 & 2 & 26 & 1 & 450 & 11 \\
\hline 2 & 7 & 24 & 3 & 450 & 3 \\
\hline 3 & 3 & 23 & 1 & 600 & 9 \\
\hline 4 & 2 & 25 & 3 & 600 & 2 \\
\hline 5 & 2 & 29 & 1 & 950 & 3 \\
\hline 6 & 2 & 28 & 3 & 950 & 1 \\
\hline
\end{tabular}




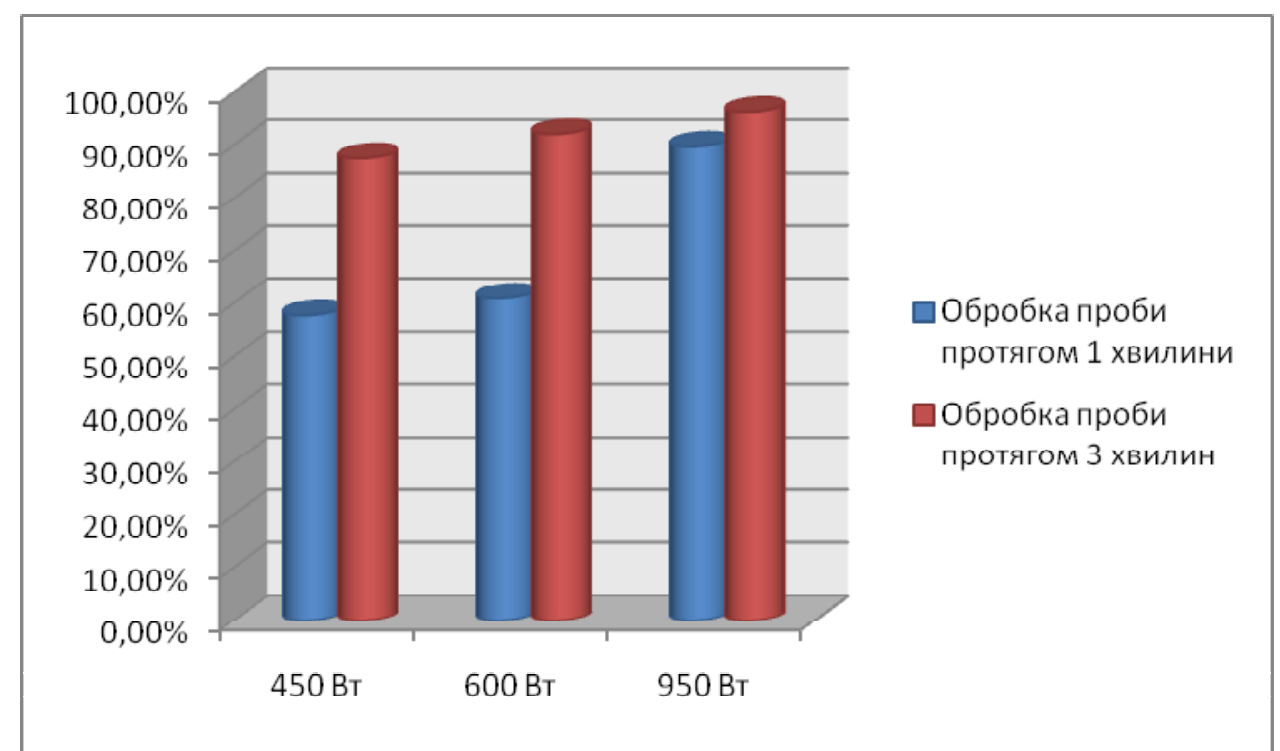

Ефективність обробки проб ковбасних виробів сумнівної свіжості

Отже, на зменшення кількості мікроорганізмів у ковбасних виробах впливають як режим потужності мікрохвильової печі, так і час обробки проб. У ході проведення досліджень було виявлено більш значний вплив часу опромінення, ніж використовуваного режиму потужності.

Висновки. Ретельно вивчивши та підсумувавши дані наукової літератури й результати власних досліджень, можна зробити висновок про ефективність обробки НВЧ-хвилями ковбасних виробів сумнівної свіжості за кількістю мікроорганізмів:

1. На зменшення кількості мікроорганізмів у ковбасних виробах впливають режим потужнос-

\section{БІБЛІОГРАФІЯ}

1. Баль-Прилипко Л. В. Технологія зберігання, консервування та переробки м'яса : [підручник] / Л. В. Баль-Прилипко. - К., 2010. - 469 с.

2. Бенников В. С. Резонансное поглощение миллиметровых волн бактериальными клетками / В. С. Бенников, С. Б. Рожков // Доклады АН CCCP. - М., 1980. - T. 255. - №3. - C. 746-743.

3. Болтовский В. С. Использование энергии ті мікрохвильової печі й час обробки зразків.

2. У ході аналізу отриманих результатів було виявлено, що час обробки проби має більш значний вплив на зменшення кількості мікроорганізмів у ній, аніж вибраний режим потужності мікрохвильової печі.

3. Тривале опромінення виробів НВЧ-хвилями (протягом 3-х хвилин) сприяє знищенню більшої кількості мікроорганізмів, але мінімальний час (1 хвилина) достатній для зменшення кількості мікрофлори ковбасного виробу сумнівної свіжості для того, щоб вважати його не шкідливим для організму людини після знезараження.

СВЧ для стерилизации пищевых продуктов / В. С. Болтовский, Г. П. Пинчук // Перспективы производства продуктов питания нового поколения. - Минск, 2005. - С. 91-94.

4. Сирохман В. I. Товарознавство м'яса і м'ясних товарів : [підручник] / В. І. Сирохман, Т. М. Лозова. - [2-ге вид., перероб. та доп.]. - К. : Центр учбової літератури, 2009. - 378 с. 